\title{
Rating of LQ-45 stock index performance credibility in Indonesia Stock Exchange
}

\author{
Tona Aurora Lubis*; Ade Octavia; Widyanti Fitri \\ Master of Management Program, Postgraduate Program, Universitas Jambi, Indonesia \\ *To whom correspondence should be addressed.Email: tonalubis@gmail.com
}

\begin{abstract}
.
This study aims to analyze stock performance credibility using the Capital Asset Pricing Model (CAPM) method, the Arbitrage Pricing Theory (APT) method, the Fama-French Three-Factor Model (FFTFM), and the 2013-2017 LQ-45 Stock Performance rating. The technique used for sampling is purposive sampling. The samples in this study are 23 companies. The results show that the CAPM model is more accurate in stock credibility assessment than the APT model and the FFTFM.
\end{abstract}

Keywords: Capital Asset Pricing Model, Arbitrage Pricing Theory, Fama-French Three-Factor Model

JEL Classification: G11, G12

\section{INTRODUCTION}

In emerging markets such as Indonesia, the company's credibility is very important, the majority of companies operating in the Indonesian stock market are more focused on the company's credibility and reputation. Biswas (2006) found that the company's reputation and credibility will positively encourages potential investors to believe and decide to invest in the company. Similarly, Sallam (2011) explained that the stock performance credibility has a positive impact on prospective investors' attitude towards promotional activities and self-image.

$\mathrm{Du}$ (2018) found that investors were very concerned about the credibility of stock performance, $\mathrm{Du}$ found strong evidence that there was no symmetrical relationship between the market and good and bad news. During the period, the study sample showed that investors were more pessimistic about bad news and doubled in believing in buying shares when situation on the stock market was in good condition. It shows that this study has a significant effect that in making stock purchase decisions, the credibility of stock performance is very important. In addition, investors are more interested in good news from national and international institutions.

According to Wijaya (2000), CAPM is a model to explain the expected return. Understanding Capital Asset Pricing Model (CAPM) is a pricing model of securities (assets) at risk in the assessment of risks usually ordinary shares are classified as risky investments. Own risk means the possibility of deviating from the actual acquisition of possibility, whereas the degree of risk is the sum of possible fluctuations (potential fluctuation).

According to Husnan (2016), APT basically uses the idea that two investment 
opportunities have identical characteristics that cannot be sold at different prices. If the assets with the same characteristics are sold at different prices, then it will be possible to arbitrate by buying cheap assets at the same time selling at a higher price in order to obtain profit without risk. The Arbitrage Pricing Theory (APT) does not use any assumptions about the market portfolio. APT only says that certain factors influence a stock's profit level; the number could be more than one.

Researches on CAPM and APT continue to develop, and many researchers are still not satisfied with CAPM and APT results. Some researchers finally found that the Fama-French Three-Factor Model (FFFTFM) is a strong model and a high level of significance in assessing the level of return and risk of shares in a company's stock performance credibility. Fama and French used three factors, namely market (CAPM), size, and book-to-market ration (APT), to explain stock portfolio returns.

Based on previous research and supporting theories on CAPM, APT and FFTFM, the researchers are interested in combining these three methods to analyze credibility ratings in LQ-45 stock groups, as these leading stocks are selected stocks that meet certain criteria in terms of good liquidity, large market capacity value, high trading frequency, good growth prospects, and good financial conditions.

\section{METHOD}

\section{Population and Sample}

The population in this study is the LQ-45 company listed on the Indonesia Stock Exchange (IDX) during the period 2013-2017. Purposive sampling was carried out on the basis of the following criteria: 1) companies registered in LQ-45 on the Indonesia Stock Exchange (IDX) that have complete and reliable financial data of the truth in 2013-2017; 2) companies in LQ-45 whose shares were actively traded on the Indonesia Stock Exchange in 2013-2017; 3) companies in LQ-45 on the Indonesia Stock Exchange (IDX) that have complete data on variables for research in 2013-2017; 4) companies that remain consistent and have never been issued in LQ-45 in 2013-2017.

\section{Types and data sources}

The data used in this study are monthly data for 2013-2017 period that includes stock prices, Composite Stock Price Index (CSPI), inflation, SBI interest rates, rupiah exchange rates, and the amount of money in circulation (MI). Data is collected from the Indonesia Stock Exchange (IDX), Bank Indonesia, and Indonesia Capital Market Directory (ICMD).

\section{Analysis tools}

Comparative analytical models are used to find differences in the accuracy of the Capital Asset Pricing Model (CAPM), Arbitrage Pricing Theory (APT), Fama-French Three-Factor Model (FFTFM) in predicting the LQ-45 index's credibility. In this study, the analysis to be used involves the following steps:

a. Testing period for testing differences in the accuracy of the CAPM, APT, and FFTFM in predicting risk and return LQ-45.

b. Calculating stock LQ-45 companies' stock returns (actual returns).

c. Calculating market returns.-

d. Calculating Beta $(\beta)$ using the formula of the market model that expresses the actual return with market return. 
e. Capital Asset Pricing Model, with the equation (Lam, 2005)

$E(R p)=R f+\beta[(R m)-R f]$

In which:

$\mathrm{Rp}=$ Return Portofolio

$\mathrm{Rf}=$ Return Risk Free Asset

$\mathrm{Rm}=$ Return Market; and

$\beta=$ Beta (volatility of share I towards premium)

f. Arbitrage Pricing Theory

To calculate the expected income securities in the APT model can be used formula as follows:

$E(R i, t)=a_{i}+b_{i 1} F_{1 t}+b_{i 2} F_{2 t}+b_{i 3} F_{3 t}+b_{i 4} F_{4 t}+b_{i 5} F_{5 t}+b_{i 6} F_{6 t}+b_{i 7} F_{7 t}+e_{i t}$

In which:

$\mathrm{E}(\mathrm{Ri}, \mathrm{t})=$ The level of expected income securities $\mathrm{i}$ in period $\mathrm{t}$

$\mathrm{Ai} \quad=$ Constants

$\mathrm{b}_{\mathrm{ik}} \quad=$ Sensitivity of security income $\mathrm{i}$ to factor $\mathrm{k}$ in period $\mathrm{t}$

$\mathrm{F} 1=$ Unexpected changes in inflation rates

F2 = Unexpected Exchange Rate of Rupiah against Dollar

F3 = Unexpected SBI Interest Rate Change

F4 = Unexpected level of circulating money

F5 = actual return

F6 = return market

F7 = return free risk

$\mathrm{e}_{\mathrm{it}} \quad=$ random error

g. Fama-French Three-Factor Model (Kampman, 2011)

$\mathrm{E}(\mathrm{Ri})=\mathrm{Rf}+\beta_{3}[\mathrm{E}(\mathrm{Rm})-\mathrm{Rf})+\mathrm{bsmb}(\mathrm{SMB})+\mathrm{bhml}(\mathrm{HML})$

In which:

$\mathrm{E}(\mathrm{Ri})=$ Expected return;

$\mathrm{Rf}=$ return risk free asset

$\mathrm{E}(\mathrm{Rm})=$ expected return market

$\beta=$ Beta

$\mathrm{bsmb}=\mathrm{SMB}$ coefficient

$\mathrm{SMB}=$ The portfolio return is made based on the size of a small company minus the size of a large company

bhml $=$ HML coefficients

HML = Returns from portfolios made based on books to high market equity are calculated by books to low market equity.

h. Mean Absolute Deviation (MAD)

The mean absolute deviation is a value calculated by taking each prediction error's absolute number divided by the number of periods of data. MAD is available for CAPM, APT and FFTFM models

\section{Variable definitions and measurements}

The definitions and measurements of variables in this study are given in Table 1 as follows: 
Table 1. Variable definitions and measurements

\begin{tabular}{ll}
\hline Variable & Definition and measurements \\
\hline Stock Return (Ri) & $\begin{array}{l}\text { difference in stock price i period t with stock price i in period t-1, } \\
\text { divided by stock price i period t-1 }\end{array}$ \\
Market Return (Rm) & $\begin{array}{l}\text { difference in period I Composite Stock Price Index with Composite } \\
\text { Stock Price Index i in period t-1, divided by period t-1 i Composite } \\
\text { Stock Price Index }\end{array}$ \\
$\begin{array}{l}\text { Risk Free Asset Return (Rf) } \\
\text { Unexpected changes in inflation } \\
\text { rates }\end{array}$ & $\begin{array}{l}\text { interest rate (SBI) for one month divided by twelve months } \\
\text { the level of the exchange rate } \\
\text { the expected inflation rate } \\
\text { of the Rupiah against the dollar } \\
\text { is unexpected }\end{array}$ \\
$\begin{array}{l}\text { Unexpected SBI Interest Rate } \\
\text { the difference from the actual exchange rate of the Rupiah against } \\
\text { the Dollar with the value of the exchange rate of the Rupiah against } \\
\text { the Dollar in the expected period }\end{array}$ \\
$\begin{array}{l}\text { Unexpected level of circulating } \\
\text { money }\end{array}$ & $\begin{array}{l}\text { difference from changes in actual SBI interest rates and changes in } \\
\text { expected SBI interest rates } \\
\text { the difference from the actual amount of money in circulation with } \\
\text { the expected amount of money in circulation }\end{array}$ \\
\hline
\end{tabular}

\section{RESULTS AND DISCUSSION}

\section{LQ-45 company stock return}

Of the 23 LQ-45 companies that were analyzed, only four companies with an average stock return per month were negative. Most of the others (19 companies) have a positive average value of monthly stock returns..

Tabel 2. Average stock returns per month of LQ-45 companies in 2013-2017

\begin{tabular}{llcc}
\hline No & Company & Code & Stock Returns \\
\hline 1 & Astra Agro Lestari Tbk & AALI & 0.0308 \\
2 & Adaro Energy Tbk & ADRO & 0.0051 \\
3 & Akr Corporindo Tbk & AKRA & 0.0108 \\
4 & Astra International Tbk & ASII & 0.0011 \\
5 & Bank Central Asia Tbk & BBCA & 0.0148 \\
6 & Bank Negara Indonesia (Persero) Tbk & BBNI & 0.0178 \\
7 & Bank Rakyat Indonesia (Persero) Tbk & BBRI & 0.0184 \\
8 & Bank Mandiri (Persero) Tbk & BMRI & 0.0132 \\
9 & Bumi Serpong Damai Tbk & BSDE & 0.0148 \\
10 & Gudang Garam Tbk & GGRM & 0.0086 \\
11 & Indofood CBP Sukses Makmur Tbk & ICBP & 0.0168 \\
12 & Indofood Sukses Makmur Tbk & INDF & 0.0062 \\
13 & Indocement Tunggal Prakasa Tbk & INTP & 0.0029 \\
14 & Jasa Marga (Persero) Tbk & JSMR & 0.0007 \\
15 & Kalbe Farma Tbk & KLBF & 0.0086 \\
16 & Lippo Karawaci Tbk & LPKR & -0.0053 \\
17 & PP London Sumatra Tbk & LSIP & -0.0018 \\
18 & Media Nusantara Citra Tbk & MNCN & -0.0017 \\
19 & Perusahaan Gas Negara (Persero) Tbk & PGAS & -0.0083 \\
20 & Tambang Batubara Bukit Asam (Persero) Tbk & PTBA & 0.1568 \\
21 & Telekomunikasi Indonesia (Persero) Tbk & TLKM & 0.0166 \\
22 & United Tractors Tbk & UNTR & 0.0095 \\
23 & Unilever Indonesia Tbk & UNVR & 0.0209 \\
\hline & & & 0.0155 \\
\hline
\end{tabular}

Source: PT. Indonesia Stock Exchange, Data processed by author 
The highest average stock return per month is Tambang Batubara Bukit Asam (Persero) Tbk (PTBA) which is equal to 0.1568 per month, whereas the lowest average return per month is shares of Perusahaan Gas Negara (Persero) Tbk (PGAS), namely 0.0083 per month.

Furthermore, average stock return per month of each LQ 45 company from 2013 to 2017 is positive at 0.0155 . It means that investors responded positively to stocks in the capital market from 2013 to 2017, particularly LQ-45 shares.

\section{Market return}

The return market was highly fluctuating between 2013 and 2017. The highest return market was 17.43 per cent in January 2015, and the lowest return market per month was -12.15 per cent in February 2016. This high fluctuation of the return market shows that the average return of all IDX-listed companies fluctuates as well.

Table 3. Average market return per month of LQ-45 companies in 2013 - 2017

\begin{tabular}{lrrrrr}
\hline \multirow{2}{*}{ Month } & \multicolumn{5}{c}{ Year } \\
\cline { 2 - 6 } & 2013 & 2014 & 2015 & 2016 & 2017 \\
\hline January & 0.0303 & 0.0289 & 0.1743 & -0.1070 & 0.0008 \\
February & 0.0756 & 0.0483 & 0.0415 & -0.1215 & 0.0126 \\
March & 0.0296 & 0.0390 & 0.0457 & -0.2033 & 0.0332 \\
April & 0.0217 & 0.0092 & -0.0671 & -0.0987 & 0.0183 \\
May & 0.0096 & 0.0099 & -0.0544 & -0.0917 & 0.0061 \\
June & -0.0465 & -0.0045 & -0.0359 & -0.0022 & 0.0139 \\
July & -0.0309 & 0.0433 & -0.0787 & 0.0862 & -0.0010 \\
August & -0.0916 & 0.0118 & -0.0843 & 0.1156 & 0.0019 \\
September & 0.0286 & -0.0043 & -0.1162 & 0.1076 & 0.0072 \\
October & 0.0454 & -0.0115 & -0.0065 & 0.1391 & 0.0149 \\
November & -0.0485 & 0.0092 & 0.0508 & 0.1143 & -0.0108 \\
December & 0.0012 & 0.0148 & 0.0340 & 0.1563 & 0.0499 \\
\hline Average & 0.0020 & 0.0162 & -0.0081 & 0.0162 & 0.0122 \\
Standard Deviation & 0.0475 & 0.0196 & 0.0813 & 0.1133 & 0.0163 \\
\hline Source: PT. Indonesia Stock Exchange, Data processed by author & &
\end{tabular}

Based on the average market return per month, it can be seen that the average market return of the lowest LQ-45 companies occurred in 2015, with a value of -0.0081 . The highest average market return occurred in 2016 amounting to 0.0162 . Nevertheless, market return fluctuations (seen from the standard deviation value) were also relatively high in that year compared to other years. The lowest monthly market return fluctuation occurred in 2014.

\section{Systematic risk of LQ-45 shares}

The risk of a stock against market risk can be measured by systematic risk. A stock's systematic risk measures the sensitivity of a security's profits in response to market profits movement.

From Table 4, it can be seen that almost all beta shares of LQ-45 sample companies are positive. Only five of the 23 companies had negative beta values, while 18 other companies had positive beta values.

The average of beta value was 0.0995 . It means the relationship between the return market and the stock returns of each LQ-45 company were in the same direction. The highest beta stock was owned by Bank Rakyat Indonesia (Persero) Tbk's equivalent of 0.5543 , meaning that Bank Rakyat Indonesia (Persero) Tbk's stock return 
was most sensitive to the return market compared to other stock returns.

On the contrary, the lowest beta was owned by Tambang Batu Bara Bukit Asam (Persero) Tbk shares, which was -3,2130. This means that the relationship between the return market and the return of Bukit Asam (Persero) Tbk's shares was inversely proportional.

Table 4. Systematic Risk or Beta of LQ-45 Companies in 2013-2017

\begin{tabular}{lllr}
\hline No & The name of the company & Code & Beta \\
\hline 1 & Astra Agro Lestari Tbk & AALI & -0.0771 \\
2 & Adaro Energy Tbk & ADRO & 0.1737 \\
3 & Akr Corporindo Tbk & AKRA & 0.7442 \\
4 & Astra International Tbk & ASII & 0.3193 \\
5 & Bank Central Asia Tbk & BBCA & 0.3578 \\
6 & Bank Negara Indonesia (Persero) Tbk & BBNI & 0.5029 \\
7 & Bank Rakyat Indonesia (Persero) Tbk & BBRI & 0.5543 \\
8 & Bank Mandiri (Persero) Tbk & BMRI & 0.5455 \\
9 & Bumi Serpong Damai Tbk & BSDE & 0.4760 \\
10 & Gudang Garam Tbk & GGRM & -0.0466 \\
11 & Indofood CBP Sukses Makmur Tbk & ICBP & 0.2028 \\
12 & Indofood Sukses Makmur Tbk & INDF & 0.1090 \\
13 & Indocement Tunggal Prakasa Tbk & INTP & 0.3189 \\
14 & Jasa Marga (Persero) Tbk & JSMR & 0.1170 \\
15 & Kalbe Farma Tbk & KLBF & 0.1620 \\
16 & Lippo Karawaci Tbk & LPKR & 0.2186 \\
17 & PP London Sumatra Tbk & LSIP & -0.0945 \\
18 & Media Nusantara Citra Tbk & MNCN & 0.1364 \\
19 & Perusahaan Gas Negara (Persero) Tbk & PGAS & 0.2510 \\
20 & Tambang Batubara Bukit Asam (Persero) Tbk & PTBA & -3.2130 \\
21 & Telekomunikasi Indonesia (Persero) Tbk & TLKM & 0.0797 \\
22 & United Tractors Tbk & UNTR & 0.4730 \\
23 & Unilever Indonesia Tbk & UNVR & -0.0231 \\
\hline & $\quad$ Average & & 0.0995 \\
\hline
\end{tabular}

Source: PT. Indonesia Stock Exchange, Data processed by author

\section{Comparison of accuracy of CAPM, APT and FFTFM in analyzing performance ratings of $L Q-45$ shares.}

Investment policymakers like the government, the private sector, investors, both institutions and individuals are very much in need of the ability to estimate the return of a security for many investment decisions. There are various methods to estimate the return of a security. Related to this, the results of CAPM, APT and FFTFM methods calculations in LQ45 companies are given in Table 1.

The average MAD CAPM model is 0.3666, the average MAD of the APT model is 0.3832 , and the average MAD of the FFTFM model is 0.4046. This shows that the MAD CAPM model is the lowest in comparison with MAD APT and MA FFTFM. Thus, the CAPM model is more accurate than the APT model and FFTFM in predicting the credibility ratings of LQ-45 stocks in the 2013 to 2017 period.

The results of this study support the research of Bucher (2016), Kun, Kim, and Taejin (2016) and Akbar and Nguyen (2015), which suggested that the CAPM has advantages that investors can use for short-term calculations; easy to use because the data needed is easy to obtain and it does not take much time to get the results of the 
stock return estimation.

CAPM provides the right prediction between the risk relationship of an asset and the level of expected return, although there is still disagreement or debate among academics and researchers. On the other hand, the CAPM shows that in historical relations there was no relationship between stock returns and market beta. One solution is therefore to develop a multivariable model; risk is assumed to be caused by a number of different factors. However, for several studies, CAPM is widely used and still has the correct accuracy widely used and still has the right accuracy.

Table 5. LQ-45 index performance in period 2013-2017

\begin{tabular}{|c|c|c|c|c|c|c|c|c|}
\hline \multirow[b]{2}{*}{ No } & \multirow[b]{2}{*}{ The name of the company } & \multirow[b]{2}{*}{ Code } & \multicolumn{3}{|c|}{ Index Performance } & \multicolumn{3}{|c|}{ MAD Index } \\
\hline & & & CAPM & APT & $\begin{array}{c}\text { FFTF } \\
\text { M }\end{array}$ & CAPM & APT & FFTFM \\
\hline 1 & Astra Agro Lestari Tbk & AALI & 0.7116 & 0.7560 & 0.1451 & 0.7103 & 0.7547 & 0.1438 \\
\hline 2 & Adaro Energy Tbk & ADRO & 0.1469 & 0.1260 & 0.3120 & 0.1467 & 0.1257 & 0.3117 \\
\hline 3 & Akr Corporindo Tbk & AKRA & 0.5459 & 0.3322 & 0.2119 & 0.5455 & 0.3317 & 0.2114 \\
\hline 4 & Astra International Tbk & ASII & 0.0381 & 0.1827 & 0.7965 & 0.0381 & 0.1827 & 0.7965 \\
\hline 5 & Bank Central Asia Tbk & BBCA & 0.1872 & 0.6137 & 0.3012 & 0.1866 & 0.6131 & 0.3006 \\
\hline 6 & Bank Negara Indonesia (Persero) Tbk & BBNI & 0.7397 & 0.3915 & 0.6780 & 0.7389 & 0.3907 & 0.6772 \\
\hline 7 & Bank Rakyat Indonesia (Persero) Tbk & BBRI & 0.8394 & 0.1030 & 0.8970 & 0.8386 & 0.1022 & 0.8962 \\
\hline 8 & Bank Mandiri (Persero) Tbk & BMRI & 0.1525 & 0.1879 & 0.6497 & 0.1519 & 0.1873 & 0.6491 \\
\hline 9 & Bumi Serpong Damai Tbk & BSDE & 0.1906 & 0.7170 & 0.2972 & 0.1900 & 0.7164 & 0.2966 \\
\hline 10 & Gudang Garam Tbk & GGRM & 0.0189 & 0.1487 & 0.3413 & 0.0185 & 0.1483 & 0.3409 \\
\hline 11 & Indofood CBP Sukses Makmur Tbk & ICBP & 0.7104 & 0.1080 & 0.4960 & 0.7097 & 0.1073 & 0.4953 \\
\hline 12 & Indofood Sukses Makmur Tbk & INDF & 0.3075 & 0.4989 & 0.2838 & 0.3072 & 0.4987 & 0.2835 \\
\hline 13 & Indocement Tunggal Prakasa Tbk & INTP & 0.1661 & 0.7316 & 0.3571 & 0.1660 & 0.7315 & 0.3570 \\
\hline 14 & Jasa Marga (Persero) Tbk & JSMR & 0.1224 & 0.6370 & 0.6276 & 0.1223 & 0.6370 & 0.6276 \\
\hline 15 & Kalbe Farma Tbk & KLBF & 0.1125 & 0.3342 & 0.6224 & 0.1121 & 0.3338 & 0.6220 \\
\hline 16 & Lippo Karawaci Tbk & LPKR & 0.9802 & 0.1908 & 0.1715 & 0.9805 & 0.1910 & 0.1717 \\
\hline 17 & PP London Sumatra Tbk & LSIP & 0.9822 & 0.2737 & 0.1005 & 0.9823 & 0.2738 & 0.1006 \\
\hline 18 & Media Nusantara Citra Tbk & $\mathrm{MNCN}$ & 0.8623 & 0.2888 & 0.1735 & 0.8624 & 0.2889 & 0.1736 \\
\hline 19 & Perusahaan Gas Negara (Persero) Tbk & PGAS & 0.1156 & 0.3398 & 0.1144 & 0.1159 & 0.3402 & 0.1147 \\
\hline 20 & Tambang BatubaraBukit Asam (Persero) Tbk & PTBA & 0.1076 & 0.2899 & 0.2220 & 0.1008 & 0.2831 & 0.2152 \\
\hline 21 & Telekomunikasi Indonesia (Persero) Tbk & TLKM & 0.1391 & 0.1462 & 0.3278 & 0.1384 & 0.1455 & 0.3271 \\
\hline 22 & United Tractors Tbk & UNTR & 0.1143 & 0.9789 & 0.3670 & 0.1139 & 0.9785 & 0.3666 \\
\hline 23 & Unilever Indonesia Tbk & UNVR & 0.1563 & 0.4519 & 0.8760 & 0.1554 & 0.4510 & 0.8751 \\
\hline & Average & & & & & 0.3666 & 0.3832 & 0.4067 \\
\hline
\end{tabular}

Source: PT. Indonesia Stock Exchange, Data processed by author

\section{CONCLUSIONS AND RECOMMENDATIONS}

\section{Conclusions}

When doing investments, investors will consider and choose high company stock returns. An analysis of the company's performance can predict the amount of stock returns to be obtained. The methods used in this study to evaluate company performance are CAPM, APT and FFTFM. Each of these methods shows a different level of accuracy.

The study concluded that the CAPM model is more accurate than APT and FFTFM in the credibility rating of the LQ-45 index performance for the period 2013 to 2017 in the Indonesia Stock Exchange. 


\section{Recommendations}

It's suggested for investors that the simplest and easiest variable in considering a company's credibility rating is the CAPM model, using only the variables of the return and market and risk of the company. For further research, it is expected that other models can be used to assess stock performance credibility.

\section{REFERENCES}

Akbar, M., Nguyen, T.T. (2015). "The explanatory power of higher moment capital asset pricing model in the Karachi stock exchange", Research in International Business and Finance. 36,241-253

Biswas D., Biswas A., Das N. (2006). "The differential effects of celebrity and expert endorsements on consumer risk perceptions. The role of consumer knowledge, perceived congruency, and product technology orientation". Journal of Advertising, 35(2), 17-31.

Bucher, A. (2016). Risk-adjusting the returns of private equity using the CAPM and multi-factor extensions. Department of Business and Economics, University of Passau, 94030 Passau, Germany.

Du, Wenti. (2018). "Who carried more credibility: An analysis of the market responses to news from the Japanese government, the Japanese central bank and international credit rating agencies". Journal of Economics and Business. 98, 3239

Husnan, S. (2016). Manajemen keuangan teori dan penerapan. BPFE. Yogyakarta.

Kampman, T., (2011). Explaining Stock Returns: the CAPM, Fama-French Three Factor Model and Carhart's Four Factor Model, Thesis. Tilburg University.

Kun Ho, Kim \& Kim Taejin. (2016). "Capital Asset Pricing Model: a Time-varying Volatility Approach". Journal of Empirical Finance. 37(C), 268-281

Lam, K. (2005). Is the Fama and French Model Better Than CAPM? Thesis. Someone Fraser University.

Sallam, M.A.A. (2011). "The Impact of Source Credibility on Saudi Consumer's Attitude Toward Print Advertisement: The Moderating Role of Brand Familiarity". International Journal of Marketing Studies, 3(4). 63-77.

Wijaya, L.I. (2000). "Model Pasar Versus Model Harga Aset Kapital (CAPM) dalam pasar yang efisien", Jurnal Ekonomi dan Bisnis. 3(1), 55-63. 